\title{
DNA BARCODING REVEALS MICRO-EVOLUTIONARY CHANGES AND RIVER SYSTEM-LEVEL PHYLOGEOGRAPHIC RESOLUTION OF AFRICAN SILVER CATFISH, SCHILBE INTERMEDIUS (ACTINOPTERYGII: SILURIFORMES: SCHILBEIDAE) FROM SEVEN POPULATIONS ACROSS DIFFERENT AFRICAN RIVER SYSTEMS
}

\author{
Herman F. VAN DER BANK ${ }^{1}$, Richard GREENFIELD ${ }^{1}$, Barnabas H. DARU ${ }^{2}$, and Kowiyou \\ YESSOUFOU ${ }^{2 *}$
}

\author{
African Centre for DNA Barcoding (ACDB), Kingsway Campus, \\ ${ }^{1}$ Department of Zoology, ${ }^{2}$ Department of Botany and Plant Biotechnology, University of Johannesburg, \\ P.O. Box 524, Auckland Park, 2006, Republic of South Africa
}

Van der Bank H.F., Greenfield R., Daru B.H., Yessoufou K. 2012. DNA barcoding reveals micro-evolutionary changes and river system-level phylogeographic resolution of African silver catfish, Schilbe intermedius (Actinopterygii: Siluriformes: Schilbeidae) from seven populations across different African river systems. Acta Ichthyol. Piscat. 42 (4): 307-320.

\begin{abstract}
Background. Under the tropics, less than $40 \%$ of known fishes are identified to species-level. Further, the ongoing global change poses unprecedented threat to biodiversity, and several taxa are likely to go extinct even before they could be described. Traditional ecological theory suggests that species would escape extinction risk posed by global threats (e.g., climate change) only by migrating to new environments. In this study, we hypothesise that micro-evolutionary changes (evolution within species and populations) are also important mechanisms for the survival of Schilbe intermedius in Africa, a continent subjected to uneven distribution of climate severity.

Materials and methods. Using the mitochondrial cytochrome c oxidase subunit I (COI) gene, known as animal DNA barcode, we tested this hypothesis by analysing the genetic diversity and phylogenetic relations between seven populations of $S$. intermedius across different African river systems.

Results. We reveal a clear geographical patterning in genetic variations, with three clear clusters (southern Africa, eastern Africa, and western Africa). In southern Africa, the South African population is distinct from that of Namibia and Botswana. In addition, within Nigerian populations of silver catfish, two sub-clusters emerged from two isolated river systems. We suggest that the phylogeographic pattern within African silver catfish populations mirror the past effects of selection and gene flow, and that the split within Nigerian silver catfish populations might be the result of micro-evolutionary adaptive responses to local selection pressures.

Conclusion. We suggest that the strong genetic difference in African silver catfish among geographically isolated river systems might be the result of in situ micro-evolutionary adaptive responses to changing environments, and that DNA barcode has potential beyond species delimitation.
\end{abstract}

Keywords: adaptation, DNA barcode, species delimitation, and population genetic differentiation

\section{INTRODUCTION}

Biodiversity is currently lost at an alarming rate (Pimm et al. 1995), and species decline is predicted to sustain over time (Mace et al. 2005). This loss is the result of multiple pressures on biodiversity, including human activities and climate change. Humans drive species loss through over-exploitation, pollution, introduction of species beyond their natural ranges, and destruction of natural habitats (aquatic, atmospheric, and terrestrial) (Western 2001). Further, climate change is predicted to be the major driver of biodiversity loss due to lags in species' ability to adjust their physiology and life histories (i.e., generation times and dispersal ability) to match new climate regimes (Willis et al. 2008, 2010).

How do species survive these pressures is a key question that requires continued investigation if we are to plan for pre-emptive conservation actions (Rice and Emery 2003, Yessoufou et al. 2012). Ecological theory has traditionally been put forth to predict species responses to pressures, and this theory suggests that only species with high dispersal ability are more likely to escape extinction (Loarie et al. 2009, Sandel et al. 2011; see also reviews in Rice and Emery 2003). However, given the current rate of habitat loss and the severity of climate velocity (Loarie et

\footnotetext{
* Correspondence: Dr Kowiyou Yessoufou, Department of Botany and Plant Biotechnology, University of Johannesburg, P.O. Box 524, Auckland Park, 2006, Republic of South Africa, phone: 000000000000, fax: 000000000, e-mail: kyessoufou@uj.ac.za.
} 
al. 2009, Sandel et al. 2011), species may not rely solely on migration as their unique survival strategy to threat (Geber and Dawson 1993). They may also rely on their adaptive ability in situ, which necessitates an evolutionary shift (changes in genetic materials within species or populations) that allows the development of adaptive characters to the changing environment (Rice and Emery 2003).

Such shift or micro-evolutionary change was thought to take place only after a very long period, but several studies have now revealed that evolutionary shift due to selection pressures can occur within a few generations (Kettlewell 1972, Endler 1986, Kinnison and Hendry 2001, Ashley et al. 2003), a finding termed 'contemporary evolution' (Stockwell et al. 2003). A thorough understanding of the role of contemporary micro-evolution in shaping phylogenetic diversity within populations and species is critical in conservation and restoration ecology, as it can help facilitate species survival ability in an uncertain future (Faith 1992, Rice and Emery 2003, Forest et al. 2007).

On the African continent, eastern Africa is reported along with southern Africa as the most vulnerable regions to climate change (Trauth et al. 2005, Olwoch et al. 2007). We therefore predict that individuals of the same species that are shared between both regions (eastern and southern Africa) and the rest of the continent would be genetically distinct as a result of adaptive micro-evolutionary changes to regional climate specificity. In this study, we test this hypothesis using individuals of African silver catfish, Schilbe intermedius Rüppell, 1832 from seven populations. Catfish represents almost $5 \%$ of vertebrate species (Nelson 1994). Along with their fossilised remains, they are found on all continents, and described as wood-eating, electric, omnivorous, and parasitic catfishes (see reviews in Hardman 2005). The Schilbeidae is a specious family of catfishes found in tropical and sub-tropical African and Asian freshwaters. The genus Schilbe is commonly known as butter- or silver catfishes and some species have been studied extensively with the aid of conventional taxonomic methods (De Vos and Leveque 1983, De Vos 1984, De Vos and Skelton 1990). Members of the genus, especially $S$. intermedius, are not only widely distributed and abundant across African river systems (ecological importance), but have also a great economic and nutritional value (source of proteins and omega three oils).

However, morphology-based identification within the group has been controversial. For instance, the presence/absence of an adipose fin was generally used to separate the southern African silver catfish into two genera, Schilbe (absence of adipose fin) and Eutropius (presence of adipose fin). Nonetheless, this has been questioned since rudimentary adipose fins were also observed on some Schilbe species ( $S$. intermedius) found in East and West Africa (De Vos 1984, Dankwa et al. 1999). In addition, there is a paucity of fish taxonomists, all paving the way for molecular diagnostic tools such as DNA barcoding for effective taxa delimitation (Nwani et al. 2011). DNA barcoding has proved very useful in accelerating species recognition, biodiversity assessment and conser- vation efforts, stock management, ecosystem monitoring, and phylogeographic studies (Radulovici et al. 2010, Nwani et al. 2011). The use of DNA barcodes facilitates identification to a high degree of certainty of various life-forms including larvae, carcass fragments, protected species, and damaged specimens (Ward et al. 2005). Its efficiency has also been proved in recent studies of freshwater fish (Hardman 2005, Ward et al. 2005, Nwani et al. 2011).

In this study, we expand on these previous studies, but focus specifically on the potential of DNA barcode in population genetic analysis. Because silver catfish is widely distributed, and is one of the most abundant fish in African river systems, it provides an ideal system to evaluate the genetic variation across different geographical locations on the continent. Such genetic variation, if any, will provide additional information that can help conservation biologists and restoration ecologists to prioritise management efforts. Specifically, we used sequences of the DNA barcode region for animals, the mitochondrial cytochrome c oxidase subunit I (COI) gene to:

assess the genetic variation within and between populations of $S$. intermedius in five African countries spanning southern, eastern and western Africa, and

evaluate species delimitation issues in the genus Schilbe.

\section{MATERIALS AND METHODS}

Sample collections. Samples of $S$. intermedius were collected from five countries (Fig. 1) and seven river-systems (see Table 1 for localities and GenBank accession numbers). Collection periods, localities, museum voucher numbers, images, measurements and DNA barcodes for the specimens processed as well as detailed laboratory protocols are freely accessible from the BOLD (Barcode Of Life Database) system (www.boldsystems.org) under the project 'Freshwater fish'. We also included in our matrix some sequences retrieved from BOLD and GenBank (Table 1). All fish samples analysed in this study are deposited at the South African Institute for Aquatic Biology.

DNA sequencing, editing, alignment, and tree reconstruction. To extract total DNA, we collected a piece of muscle or fin from each individual and preserved it in absolute ethanol. DNA extraction, polymerase chain reactions (PCR), and sequencing of COI region were done at the Canadian Centre for DNA Barcoding (CCDB) using the primer pair C_FishF1t1/C FishR1t1 and $\mathrm{M} 13 \mathrm{~F} / \mathrm{M} 13 \mathrm{R}$. PCR reactions and sequencing followed the standard CCDB protocol. After editing the sequences, alignment was performed using Multiple Sequence Comparison by Log-Expectation (MUSCLE vs. 3.8.31; Edgar 2004). Subsequent adjustments were made manually when necessary.

Tree reconstruction was done using Bayesian approach as implemented in MrBayes 3.1.2 (Ronquist and Huelsenbeck 2003). The best-fit model of DNA sequence evolution was chosen using jModelTest 0.1.1 (Posada 2008) under the Akaike information criterion (Posada and 
Buckley 2004). The TrN + I model was selected and used to generate the Bayesian tree. Analysis was run for nine million generations with a sampling of one tree every 100 generations. Two independent Bayesian analyses with four differentially heated chains were performed simulta- neously. The results were visualised and checked using MEGA, and 25000 trees were discarded as burn-in. For the purpose of population comparisons based on mean phylogenetic distance, the tree generated was ultrametricised using the function 'chronopl' in the R package Ape

Species-units, localities and GenBank numbers of studied individuals of Schilbe intermedius

Table 1

\begin{tabular}{llcl}
\hline Country & Localities & $N$ & GenBank numbers and composition of species-units \\
\hline South Africa Olifants River & 1 & HM914615, HM914636, HM914637, HM914638, \\
& Pongola River & & HQ567339, HQ567372 \\
& & & HQ959706, HQ959707 HQ959708, HQ959709, HQ959730, HQ959731, \\
& & & HQ959732, HQ959733, HQ959734 \\
\multirow{2}{*}{ Botswana } & Okavango Delta & 1 & GU682242, GU682243, HQ959672, HQ959673, HQ959674, HQ959688 \\
Namibia & Cunene River & 1 & JN313450, JN313451, JN313455, JN313456, JN313457 \\
Kenya & Tana River & 1 & HQ959726, HQ959727-10, HQ959728, HQ959729 \\
Nigeria & Otuocha, Anambra State & 1 & HM882935, HM882936, HM882940, HM882941, HM882962 \\
& Abakaliki, Ebonyi State & 2 & HM882944, HM882945, HM882946, HM882947, HM882948, HM882934 \\
\hline
\end{tabular}

Numbers in italics are of public access sequences by Nwani et al. (2011) from the two species-units identified in Nigeria; $N=$ species-units identified in this study.

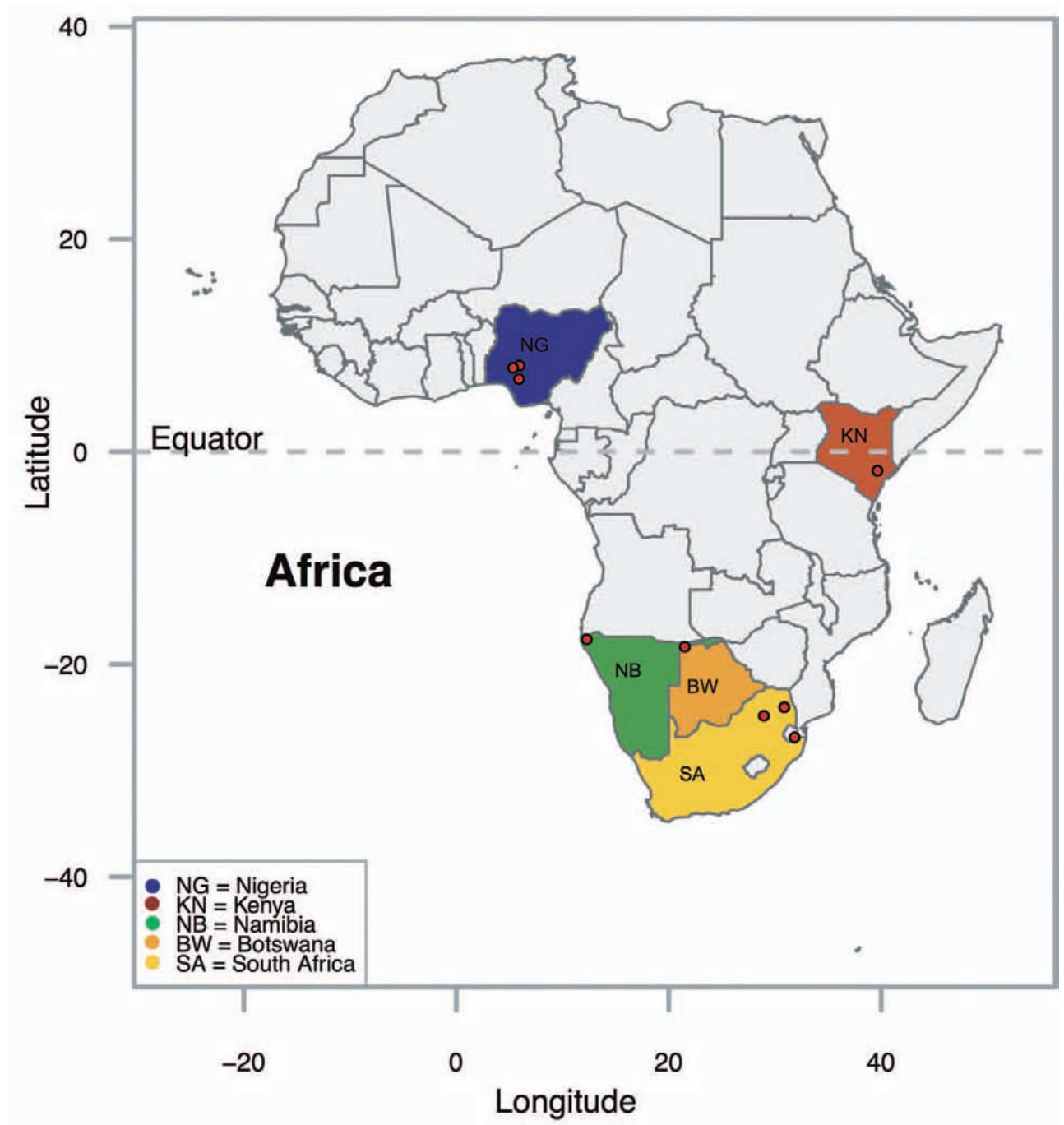

Fig. 1. Localisation of countries and rivers where samples of Schilbe intermedius were collected; Red dots indicate rivers localisation within countries 
(Paradis et al. 2004). This function estimates the node ages of a tree using a semi-parametric method based on penalised likelihood (Sanderson 2002). The branch lengths of the input tree are interpreted as mean numbers of substitutions per site. Nodes support was assessed using posterior probability $(\mathrm{PP})$ as follows: $\mathrm{PP}>0.95$ : high support and PP < 0.95: no support (Alfaro and Holder 2006).

For comparison purpose, we also reconstructed a tree based on maximum parsimony (MP) approach. MP tree searches were done using heuristic searches with 1000 random sequence-additions. Tree bisection-reconnection was performed with all character transformations treated as equally likely i.e., Fitch parsimony (Fitch 1971). MP trees were assembled using PAUP* (Swofford 2003). Node support was assessed using bootstrap (BP) values: $\mathrm{BP}>70 \%$ for strong support (Hillis and Bull 1993, Wilcox et al. 2002). We used S. mystus (L.) (without adipose fins) and Pseudopimelodus pulcher (Boulenger, 1887) (with adipose fins) as outgroups for phylogeny reconstruction.

\section{Data analyses}

Genetic differentiation between populations. All analyses were conducted in the R package Spider 1.1-1 (Brown et al. 2012). We imported and read our DNA matrix using the function 'read.dna' which also estimates the single base composition in the matrix. To estimate the GC composition, we conducted a 'sliding window analysis'. This consists of dividing up the COI DNA alignment (650 base pairs or bp) into multiple smaller fragments or 'windows' (here $300 \mathrm{bp}$ ) throughout the length of the region. This sliding process was performed using the function 'slidingWindow' in Spider. We then assessed the change in GC composition across the $S$. intermedius sequences using the function 'sapply' and the Ape command 'GC.content' (Paradis et al. 2004) across all the windows. This was conducted for each matrix (COI matrix from each country), and the significance of the differences in GC content across countries was tested using Wilcoxon ranked sum test. Further, we estimated the level of divergence in COI sequences across samples from each country using the Tajima's $K$ index (Tajima 1983). This index estimates the number of substitution between sequence pairs and the number of substitutions per nucleotide. A visual representation of DNA sequences from different samples was also presented using the function 'seeBarcode' also implemented in Spider. The genetic distance was assessed as $\mathrm{K} 2 \mathrm{P}$ distance between sequences, and was used to evaluate the 'barcoding gaps' between specimens of different origins.

Phylogenetic relations between populations. We assessed the patterns of phylogenetic relatedness between $S$. intermedius of different geographical origins using the Bayesian ultrametric phylogeny. We therefore quantified the mean phylogenetic distance (MPD) using the function 'comdist' implemented in the $\mathrm{R}$ package Picante 1.2. (Kembel et al. 2010). MPD values indicate the phylogenetic distance between pairs of individuals randomly drawn from two distinct river systems. These distances (MPD values) were then used in a cluster analysis (phyloordination) to group populations of $S$. intermedius based on the evolutionary similarity of their members.

Barcoding test of species delimitation. We conducted a species delimitation analysis to estimate the likely number of species in our sampled specimens. Prior to this evaluation, we first determined the genetic distance suitable as threshold for species delimitation using the function 'threshOpt' implemented in Spider. This function calculates the number of true positive, false negative, false positive, and true negative identifications at different potential thresholds, allowing us to determine the cumulative error (i.e., false negative + false positive). The optimised threshold is then identified as the one for which the cumulative error is lowest (Brown et al. 2012). We then applied this threshold to assess the likely number of species in the dataset using the function "tclust" also implemented in Spider. This function identifies clusters (species-units) excluding individuals greater than the threshold from any unit (Brown et al. 2012).

\section{RESULTS}

We first evaluated the composition of COI DNA sequences and genetic distances between individuals from the same geographical regions (Table 2). Single base composition is very similar across geographical regions, but GC composition in windows of $300 \mathrm{bp}$ varied significantly between regions (Wilcoxon test, $P<0.001$ ), except

Table 2

Characteristics of COI sequences of populations of Schilbe intermedius across Africa

\begin{tabular}{|c|c|c|c|c|c|c|c|c|c|}
\hline \multirow{2}{*}{ Country } & \multirow{2}{*}{$n$} & \multicolumn{4}{|c|}{ Proportion SBC [\%] } & \multirow{2}{*}{$\frac{\text { GC Comp. }}{\text { Median }}$} & \multirow{2}{*}{$\mathrm{K} 2 \mathrm{P}$} & \multicolumn{2}{|c|}{ No. of substitutions } \\
\hline & & $\mathrm{A}$ & $\mathrm{C}$ & $\mathrm{G}$ & $\mathrm{T}$ & & & Mean bts & Mean pn \\
\hline Kenya & 4 & 24.3 & 29.6 & 18.4 & 27.7 & 0.492 & 0.0015 & 2.27 & 0.0035 \\
\hline Botswana & 6 & 26.5 & 29.7 & 16.7 & 27.1 & 0.468 & 0.0035 & 2.27 & 0.0035 \\
\hline Namibia & 5 & 26.2 & 29.9 & 17.0 & 26.9 & 0.473 & 0 & 0 & 0 \\
\hline South Africa & 15 & 25.4 & 29.8 & 17.3 & 27.5 & 0.477 & 0.0008 & 0.51 & 0.0008 \\
\hline Nigeria & 11 & 26.0 & 28.6 & 17.1 & 28.4 & 0.458 & 0.0044 & 2.84 & 0.0044 \\
\hline
\end{tabular}

$n=$ number of sequences analysed per country; Proportion SBC = Proportion of single base content; GC Comp. $=$ GC Composition in windows of $300 \mathrm{bp}$; K2P = K2P intra-population distance; No. of substitutions = Tajima's $K$ index of divergence (Tajima 1983); Mean bts = mean between two sequences; Mean pn = mean per nucleotide. 
between South Africa and Namibia (Wilcoxon test, $P=0.07$; Table 2; Figs. 2 and 3). We also assessed the level of divergence within countries using Tajima's $K$ index of divergence. We found that the number of substitution between sequence pairs and the number of substitution per nucleotide varied from 0 (Namibia) to 2.84 (Nigeria) and from 0 (Namibia) to 0.0044 (Nigeria), respectively. However, the number of substitutions (between sequence pairs and per nucleotide) was identical between Kenya and Botswana (2.27 and 0.0035, respectively). Pattern of substitutions was also graphically represented as barcodes of each population from different countries, and this indicates variations and similarity at each position (Fig. 4). Further, the genetic distances (K2P distances) between individuals from the same country are $<0.005$ (i.e., ranged between 0 in Namibia and 0.0044 in Nigeria).

The phylogeny we reconstructed is well supported and indicates that the Nigerian and Kenyan populations are successively sisters to the remaining populations and diverged earlier. This topology is supported with morphological characters such that Nigerian and Kenyan specimens often lack or exhibit rudimentary adipose fin whilst South African specimens always exhibit adipose fin, which has never been observed in Namibia and Botswana (Figs. 5 and 6).

We also assessed the phylogenetic relatedness of individuals drawn randomly from two different countries. We found a clear geographical pattern such that individuals from the same country clustered on a phylogeny (Figs. 5 and 6). There was no association between absence, rudimentary or presence of adipose fins and country of origin (Figs. 5 and 6). However, southern African individuals (Namibia, Botswana, and South Africa) were more closely related and form a cluster clearly distinct from that of eastern (Kenya) and western Africa (Nigeria) (Fig. 7). Crucially, western African individuals (Nigeria) were less related to the eastern African population (Kenya), which was also distinct from the southern African populations (Fig. 7). In addition, within the southern African cluster, Namibian and Botswanan populations were more closely related to each other than to the South African populations (Fig. 7).

Variation in GC composition across geographical regions coupled with geographical patterns in phylogenetic ordination of individuals suggested that African populations of $S$. intermedius might be composed of cryptic species. We then tested this hypothesis using the barcoding approach of species delimitation. Prior to this test, we evaluated the distance threshold suitable for both the complete DNA matrix (i.e., combined DNA sequences of all countries) and the country-level DNA matrix. Using the complete dataset, we found an optimised threshold of $0.5 \%$ (Fig. 8). Based on this threshold, our barcoding analysis of species delimitation revealed six species-units such that all individuals from a given country clustered as a species-unit (Kenya, Botswana, Namibia, and South Africa), with individuals from Nigeria split in two species-units (Table 1).

In addition to the test at broader scale, we also performed a barcoding test of species delimitation at finer scale (i.e., at country level). We found that the optimised threshold was contingent upon the origin of the individuals. Specifically, we found that a threshold of $0.4 \%$ was appropriate for species delimitation in Kenya, $0.2 \%$ in Botswana, $0.1 \%$ in Namibia and South Africa, and 0.5\% in Nigeria (Fig. 9). Using these distance thresholds in species delimitation tests within each population (i.e., within each country), our result corroborated that of combined analysis, i.e., we found two species-units in Nigeria but only one species-unit in each of the remaining four countries (Table 1).

Adopting the six species-units revealed by species delimitation test, we then assessed barcoding gaps within the complete dataset. We found a significant barcode gap such that "interspecific" distance (here defined as distance between individuals of different countries) was significantly higher than "intraspecific" distance (distance within individuals of the same country) (Wilcoxon test, $P<0.001$; Fig. 10A), and that for each sequence, interspecific distance is always higher than intraspecific distance (Fig. 10B).

\section{DISCUSSION}

Fisheries are important sources of protein for human, but also play an important role in aquatic ecosystems. However, less than $40 \%$ fishery captures in tropical regions is described to species level (Caddy and Garibaldi 2000). In combination with the current threats that could originate from various sources, such as climate change, pollution, habitat destruction, over-exploitation, etc. (Hughes et al. 1997), the limited knowledge of fish diversity implies that some species are likely to go extinct before they are described; this raises the necessity of furthering our knowledge of fish diversity. In this study, we investigate the genetic diversity and species delimitation within African silver catfish. We found a geographical pattern in genetic differentiation among populations such that West African populations are genetically distinct from the eastern African

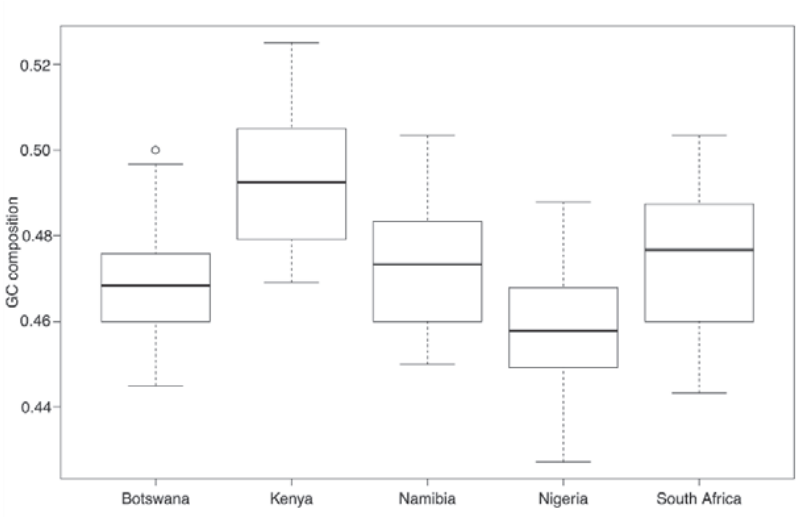

Fig. 2. Boxplots showing the GC composition of samples of Schilbe intermedius in windows of $300 \mathrm{bp}$ in COI sequences from various countries; The bottom and top of boxes show the first and third quartiles respectively, the median is indicated by the horizontal line, the range of the data by the vertical dashed line and outliers (points outside 1.5 times the interquartile range) by circles 


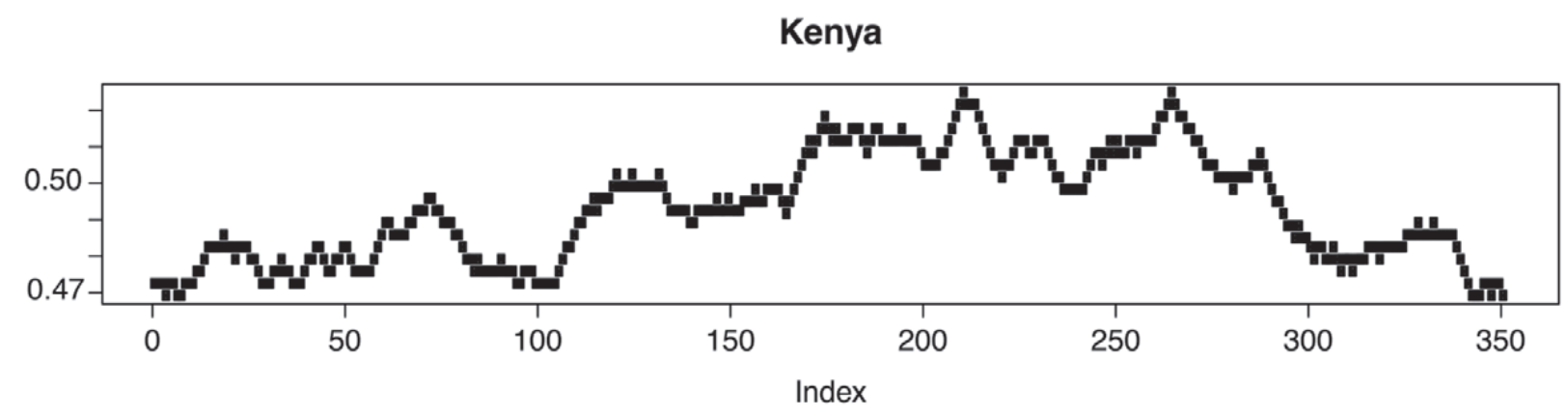

Botswana
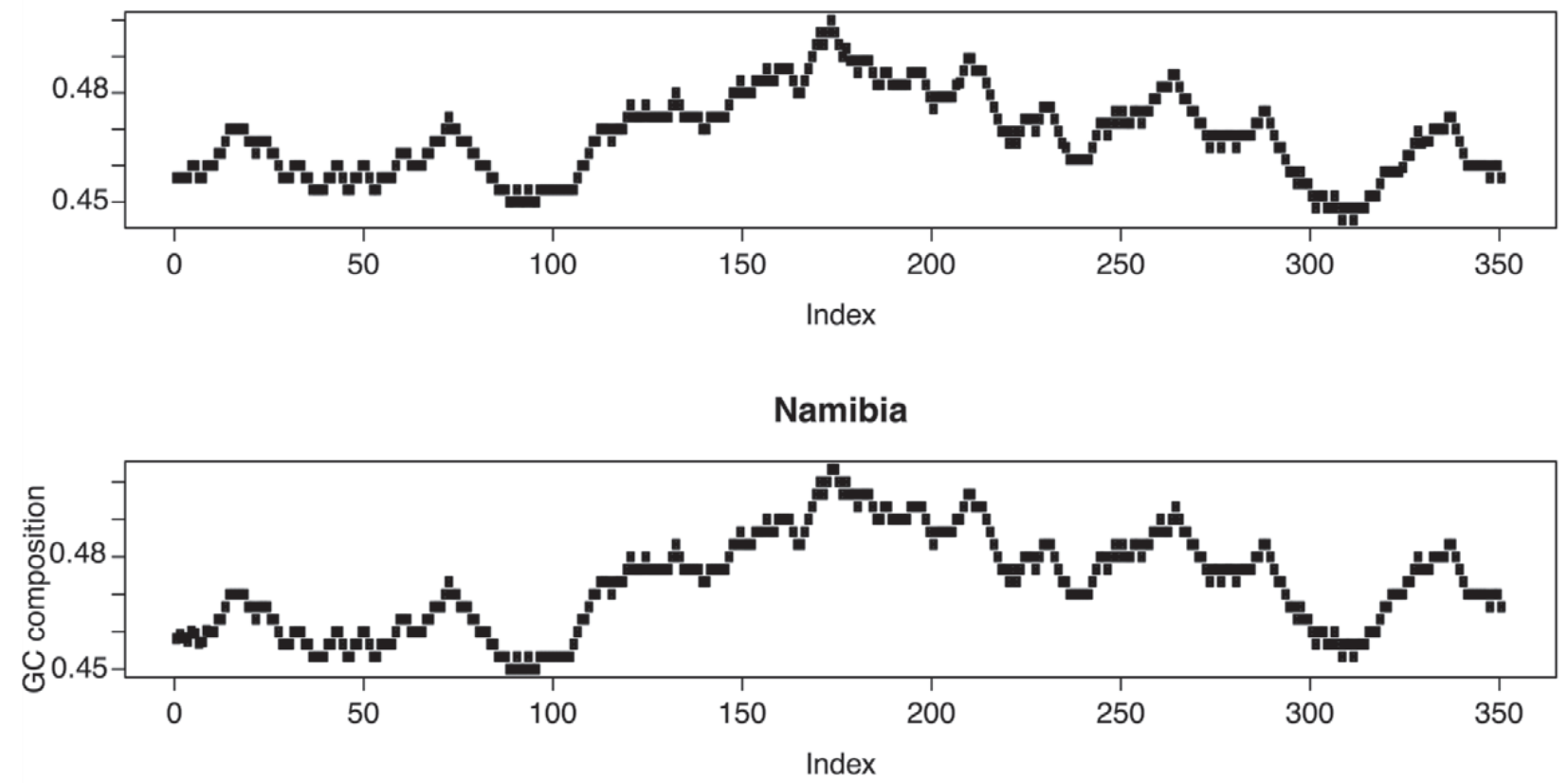

South Africa

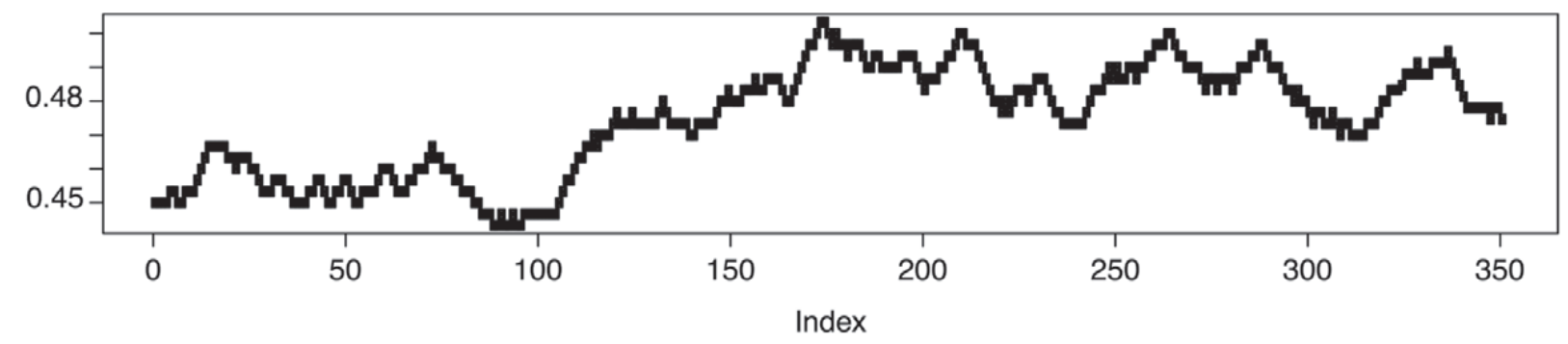

Nigeria

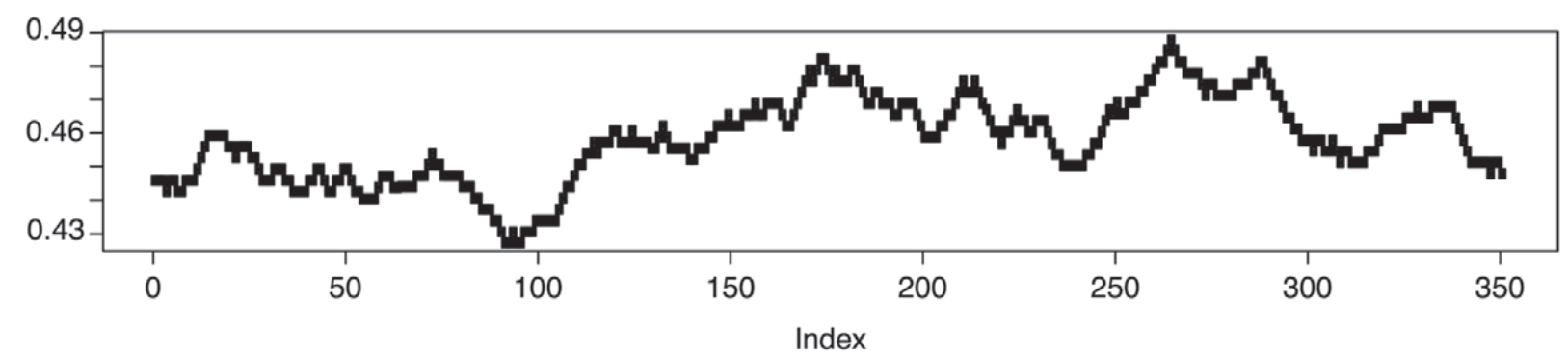

Fig. 3. Average GC content of 300 bp windows across Schilbe intermedius sequences generated from five countries 
populations, which are also genetically less related to southern African populations. Within southern African populations, individuals recorded in South Africa also form an isolated cluster as compared to Namibian and Botswanan populations, which both are more closely related. Such strong phylogeographical pattern is surprising as all individuals included in this study belong to the same species. Therefore, an explanation is required.

All African river systems were once connected (Greenwood 1983), especially during the pluvial period in the Pleistocene (Roberts 1975). This connectivity might favour gene flow between freshwater fish, thus increasing the ability of less-fitted species or populations to escape extinction under selection pressures (Brown and Kodric-Brown 1977). However, during the Pleistocene up until 8000 to 12000 years ago (especially in inter-pluvial periods) characterised by desert expansion and water retraction, African river systems became isolated, reducing the possibility of gene flow. As such, the survival of aquatic species would rely fundamentally on their ability to shift their biology to fit into the local environmental conditions (Roberts 1975). Species that fail the shift are likely to face a high risk of extinction. Such in situ adaptive evolutionary responses or micro-evolutionary changes are more likely in the context of isolated river systems where species cannot move to a more suitable river; this can result in a very high intraspecific genetic variation, because only populations with higher levels of heritable genetic variation are more likely to shift to a new optimal character under an intense selection pressure (Gilpin and Soulé 1986).

Because eastern- and southern Africa are the geographic regions most vulnerable to climate change in Africa, it is not surprising that we found a geographic pattern in genetic differentiation among populations of $S$. intermedius, with these two populations distinct from western African populations. We therefore suggest that variation in climate severity (and probably other selection pressures) across Africa coupled with isolation of water systems during the Pleistocene may be an important driver of the current geographic patterning of genetic differentiation that we found within the silver catfish populations.
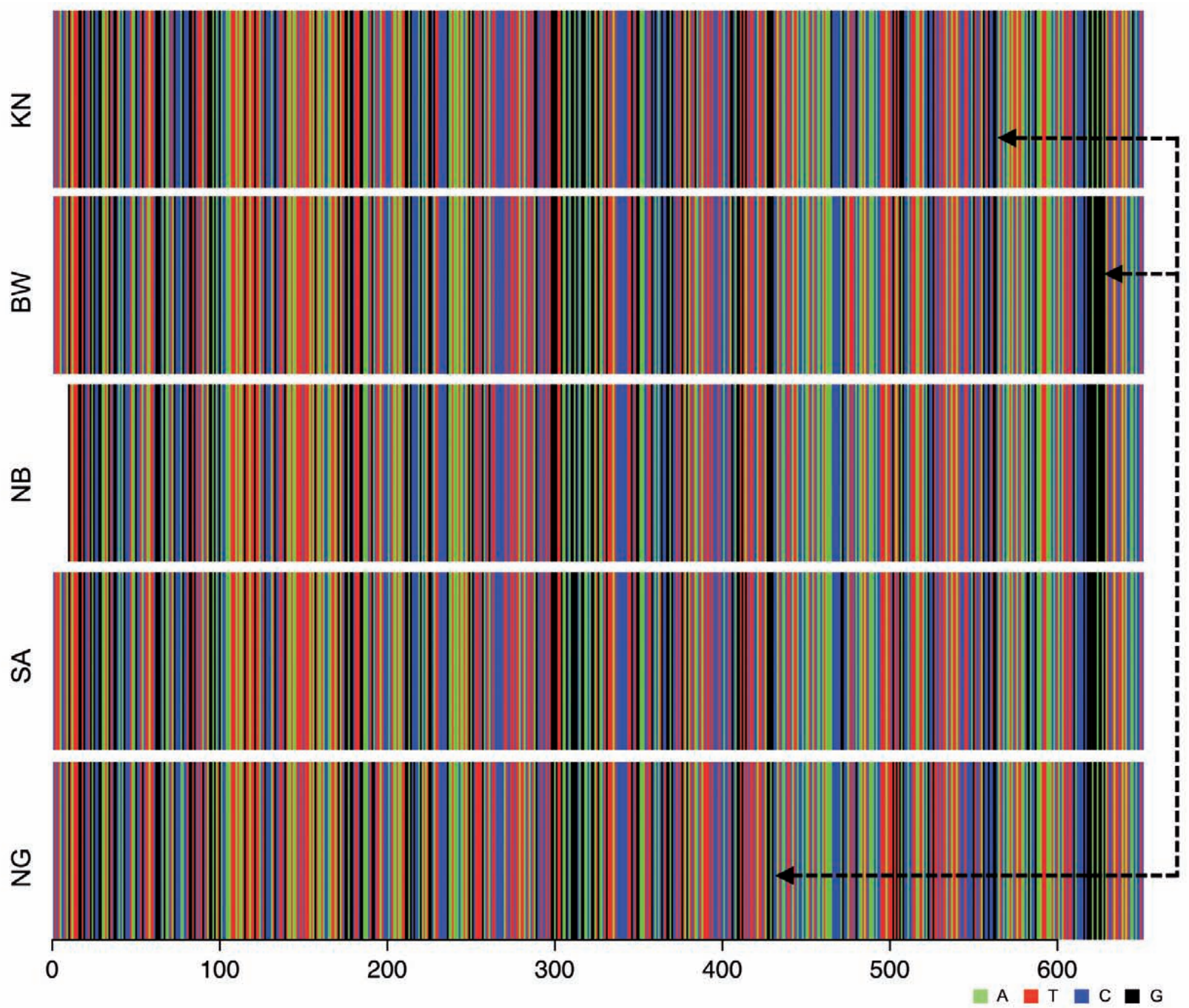

Fig. 4. Graphical representations of COI DNA barcode of Schilbe intermedius; $\mathrm{KN}=$ Kenya, BW = Botswana, $\mathrm{NB}=$ Namibia, $\mathrm{SA}=$ South Africa, $\mathrm{NG}=$ Nigeria; Base positions are indicated at an interval of $100 \mathrm{bp}$ and the comparison of sequences at these positions (examples given using dashed arrows) indicates genetic variation between specimens; colours indicate different nucleotides (see legend) 
We then hypothesise that this genetic differentiation, as adaptation process, can lead to an 'ecosystem-dependent adaptive radiation' (Ernst et al. 2003) within African populations of silver catfish. In other words, we suggest that geographically isolated individuals of $S$. intermedius may belong to different species, as opposed to the single species of $S$. intermedius currently identified. To test this hypothesis, we performed a DNA barcoding test of species delimitation on the DNA matrix of all individuals included in this study. The test reveals six species-units, each corresponding to a specific geographic origin with two species-units in Nigeria. The match between speciesunits and geographical origins provides support to our suggestion that cryptic species may exist within individuals of $S$. intermedius. We found a significant barcode gap between individuals of different origins, which provides further basis for splitting $S$. intermedius in different species taking geographical origins into account. Our finding provides further support to recent studies based on allozyme and DNA sequence data (Van der Bank et al. 1998) and DNA barcoding (Nwani et al. 2011), where substantial genetic variation between geographically isolated silver catfish was also identified. Whilst the phylogeographic pattern within African silver catfish populations might mirror the past effects of selection and gene flow, the split within Nigerian silver catfish populations into two species-like units indicates the "potential for further adap- tive change in response to local selective challenges' (Rice and Emery 2003).

However, morphology-based identification within the taxonomic group Schilbeidae is controversial. For instance, based on presence/absence of an adipose fin, southern African silver catfish were separated into two genera, Schilbe (absence of adipose fin) and Eutropius (presence of adipose fin), but this character has been shown unreliable to discriminate between the two genera since rudimentary adipose fins were also observed on some Schilbe species (S. intermedius) found in East and West Africa (De Vos 1984, Dankwa et al. 1999). As a consequence, Eutropius depressirostris (Peters, 1852) and $S$. mystus (L.) were considered to be synonymous to S. intermedius (see De Vos and Skelton 1990, Froese and Pauly 2012). Furthermore, an electrophoretic analysis of individuals of S. mystus and E. niloticus from West Africa indicated that there might be some cryptic species in S. mystus, and revealed a close similarity between the west African E. niloticus and the southern African Schilbe species (Abban and Skibinski 1988). The isolation theory was put forth to explain this similarity, suggesting that it might be the result of adaptive response of populations of $E$. depressirostris (only known then in eastern and southern Africa), that might be geographically isolated. Moreover, these two genera were shown to be geographically isolated (Bell-Cross 1972). Eutropius depres-

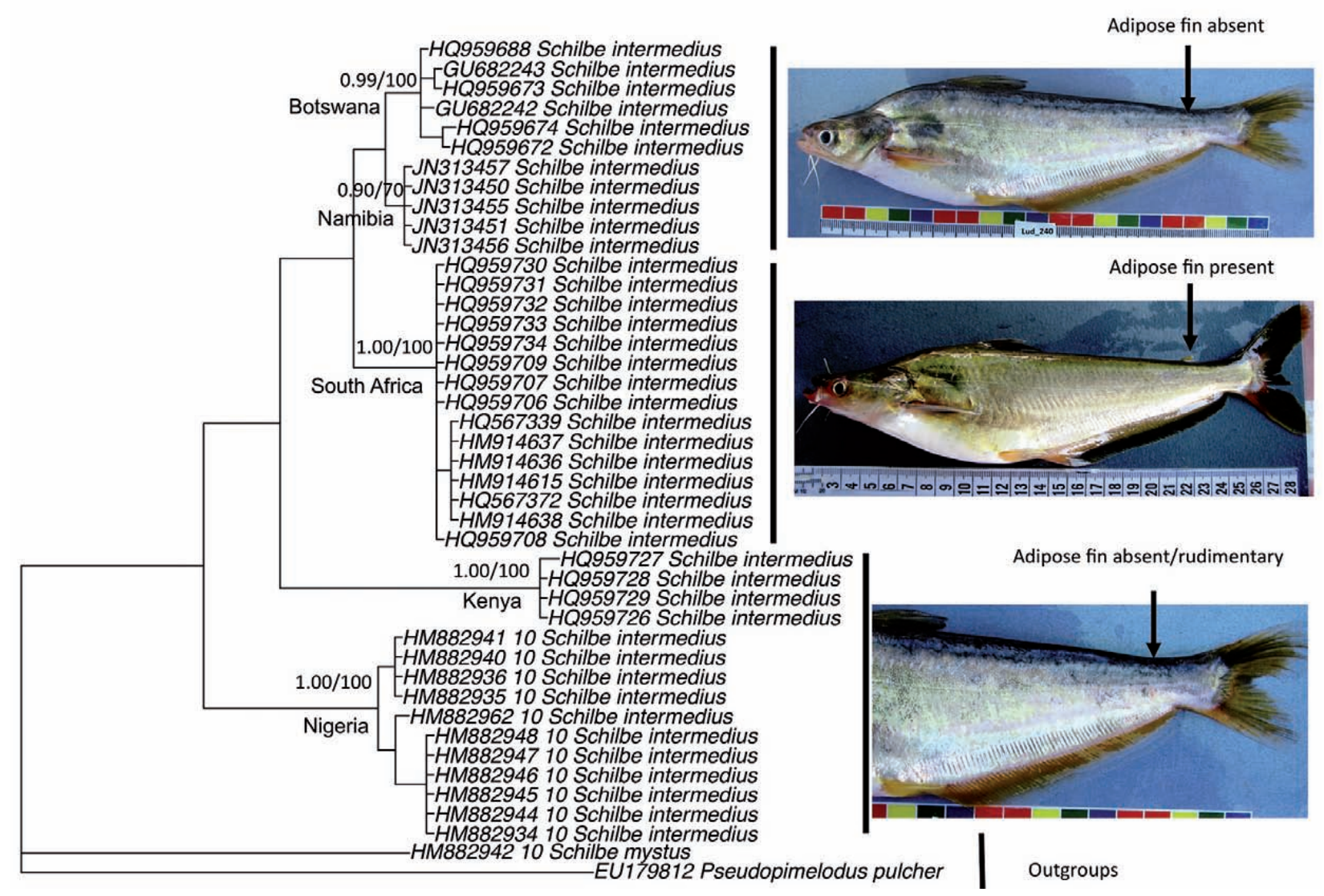

Fig. 5. Bayesian phylogeny depicting phylogeographic and morphological patterns (photographic illustrations) in populations of Schilbe intermedius; Values indicated are posterior probability/bootstrap; Countries of origins are also indicated at corresponding nodes 
sirostris, occurred in the east flowing rivers of Africa (from Kenya in the north up to as far south as the Pongola River System in KwaZulu-Natal in South Africa) (BellCross and Minshull 1988, De Vos and Skelton 1990) whereas the distribution of $S$. mystus is further down to southern Africa (the Cunene and Zambezi River Systems in Namibia, Botswana, Zambia below the Victoria Falls, and the lowveld river systems of Zimbabwe, Mozambique, and KwaZulu-Natal Province of Sout
Africa. In this study, and from a phylogenetic viewpoint, we found no association between absence, rudimentary or presence of adipose fins and geographical locality (Fig. 6). This finding indicates that the sole use of presence/absence of adipose is insufficient, and that the genetic consideration (as indicated in this study) should also be taken into account not just to solve the controversy surrounding species delimitation within the group, but also for a broad assessment of fish biodiversity.

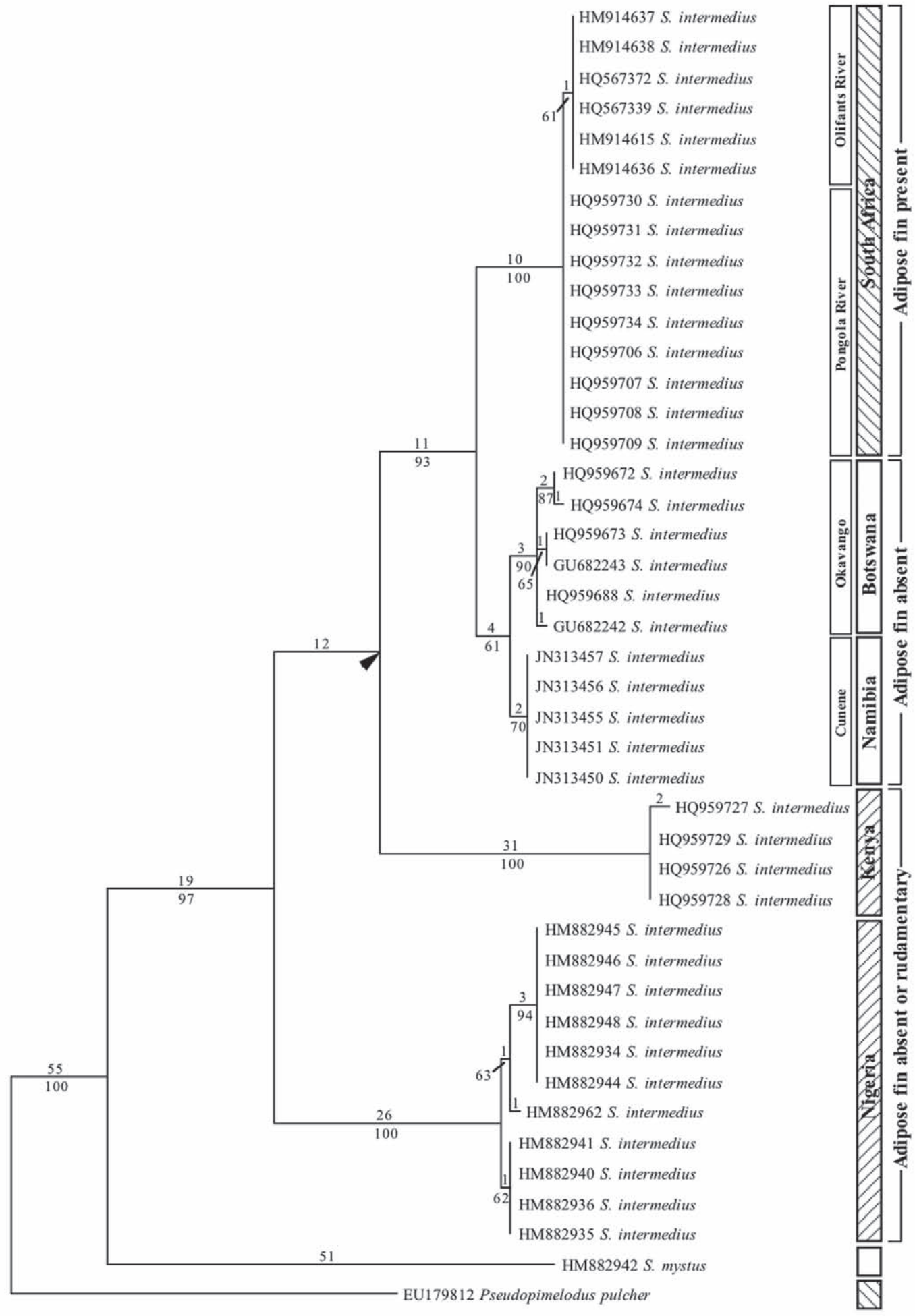

Fig. 6. Maximum parsimony phylogeny indicating phylo-geographical patterns of Schilbe intermedius specimen 
Our finding of species-units recovered according to geographical origins (barcoding test of species delimitation) indicates that there is enough variation and differentiation between and within populations, and therefore cast doubt upon the current lumping of all African silver catfish in a single species based on presence/absence of adipose fins. We suggest here that cryptic species exist within the silver catfish populations and confirm the utility of DNA barcode of $650 \mathrm{bp} \mathrm{COI} \mathrm{in} \mathrm{biodiversity} \mathrm{assessment}$ (see also Ward et al. 2005 and Nwani et al. 2011 for fishes; Hebert et al. 2004, Hajibabaei 2006a, and Hajibabaei et al. 2007 for other groups). There are several morphological, ecological, geological and geographical evidences that support our view.

First, the presence of the adipose fin in South African populations and its absence in Okavango (Botswana), Cunene (Namibia) and Upper Zambezi populations were consistently observed in field studies. The rudimentary/absence of adipose fins in central African populations needs further analyses.

Second, it is also supported by geological data. The Cunene and Nigerian rivers are the only west-flowing ones in our study; they are isolated from the other African rivers. Also, the Victoria and Kafue falls and the Rift Valley present very efficient barriers to fish distribution and to isolate species in southern Africa. Furthermore, there is no geographic evidence of river captures or linking between the Limpopo (South Africa) and Upper Zambezi river systems (Wellington 1955, Partridge and Maud 1987), although several authors speculated on a linkage between the Lower Limpopo and the Lower Zambezi rivers (Gaigher and Pott 1973, Bowmaker et al. 1978). This is based on the presence of certain fish species (e.g., former $E$. depressirostris) in the systems mentioned, which do not occur in other parts of the river (i.e., the Upper Zambezi or Okavango rivers). The link between the Limpopo and Lower Zambezi rivers probably extended into KwaZulu-Natal, and it is assumed that KwaZuluNatal received the remainder of its species via this route (Gaigher and Pott 1973).

Third, substantial DNA sequence variations were obtained. Fourth, there are fixed allelic mobility differences at one locus between the northern and southern fish populations (Van der Bank et al. 1998). The existence of allele mobility differences between populations is a significant evolutionary event in the evolutionary history of a species since this indicates that gene flow has been very low or absent for a very long time to allow speciation to occur. Finally, ecological, morphologic, allozyme, DNA sequence data, phylogenetic analyses and DNA barcoding test (this study) consistently separated the two central and the southern African populations of S. intermedius from each other, and provides strong support to the recognition of different species.

Nonetheless, there are two situations where the efficiency of $650 \mathrm{bp}$ COI can be hampered. When DNA is degraded such as in processed biological materials (e.g., food), DNA strands longer than 200 bp become unlikely to

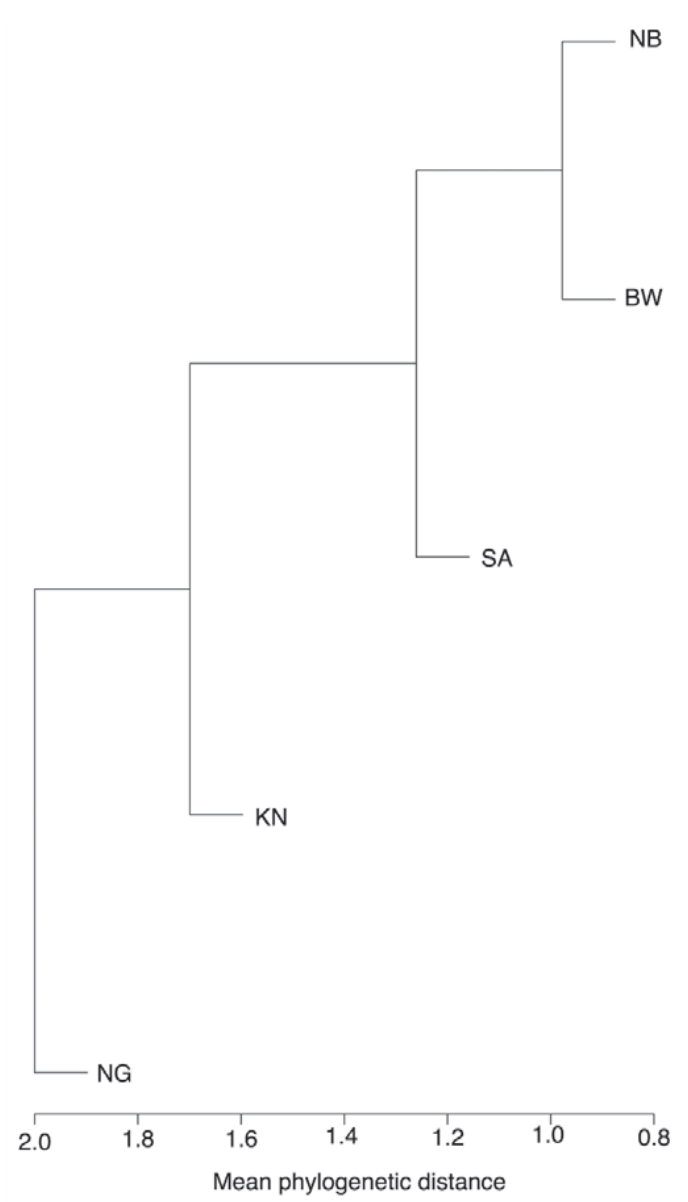

Fig. 7. Phylo-ordination indicating phylogenetic relatedness between specimens of Schilbe intermedius from different countries; Phylogenetic relatedness was compared using the mean phylogenetic distance (MPD); $\mathrm{KN}=$ Kenya, $\mathrm{BW}=$ Botswana, $\mathrm{NB}=$ Namibia, SA = South Africa, $\mathrm{NG}=$ Nigeria; Height is in unit of MPD, i.e., the mean number of substitutions per site

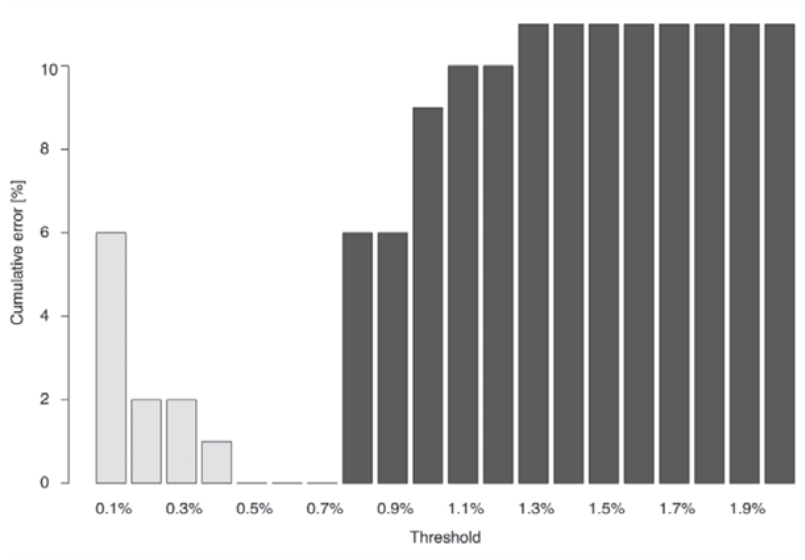

Fig. 8. Bar-plot showing the false positive (light grey) and false negative (dark grey) rate of identification of Schilbe intermedius as pre-set thresholds change; Cumulative error equals the sum of false positive and false negative 


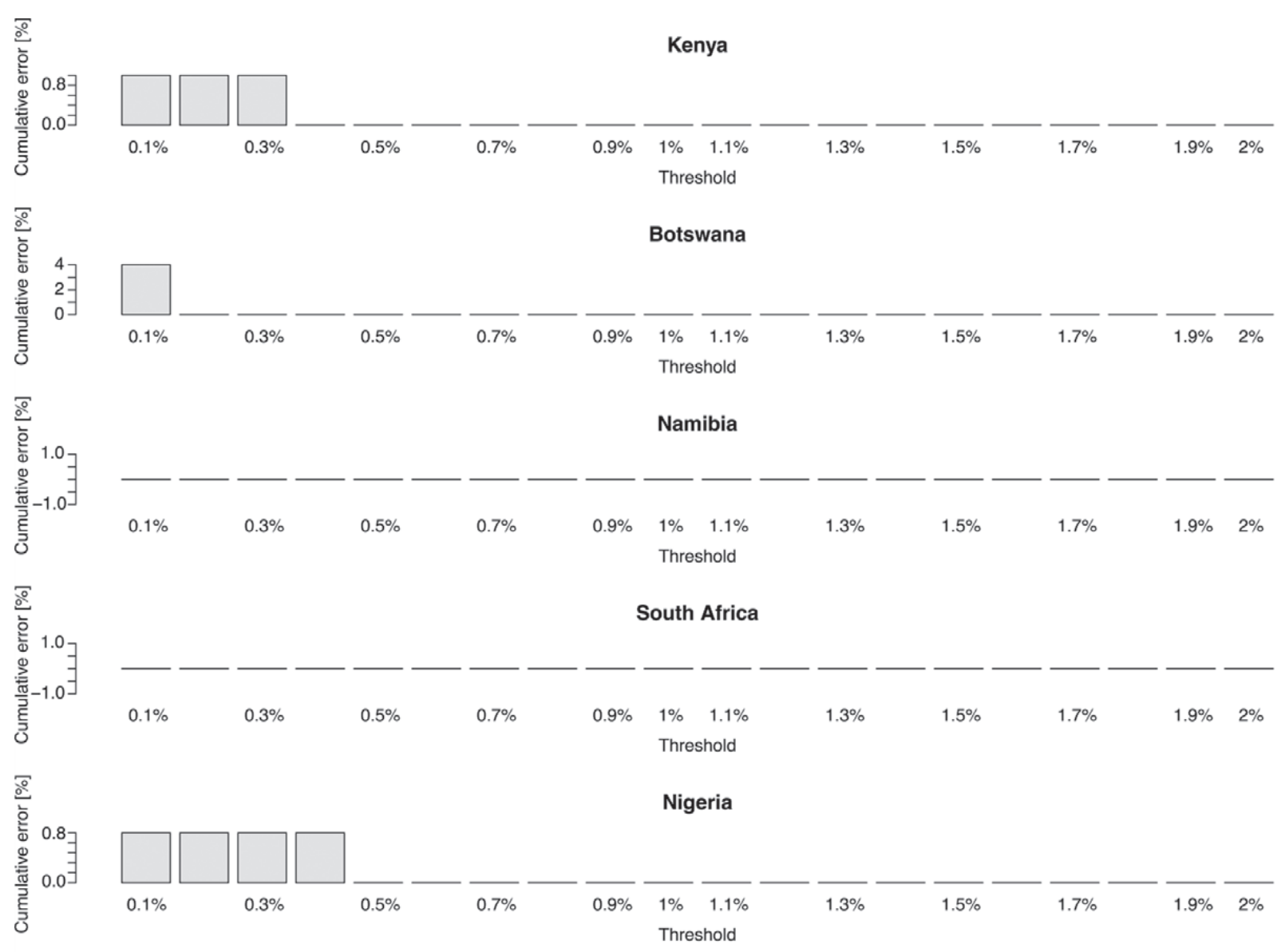

Fig. 9. Bar-plot showing the false positive (light grey) rate of identification of Schilbe intermedius specimens (per country) as pre-set thresholds change; The false negative rate of identification of $S$. intermedius is null so that cumulative error equals false positive

A

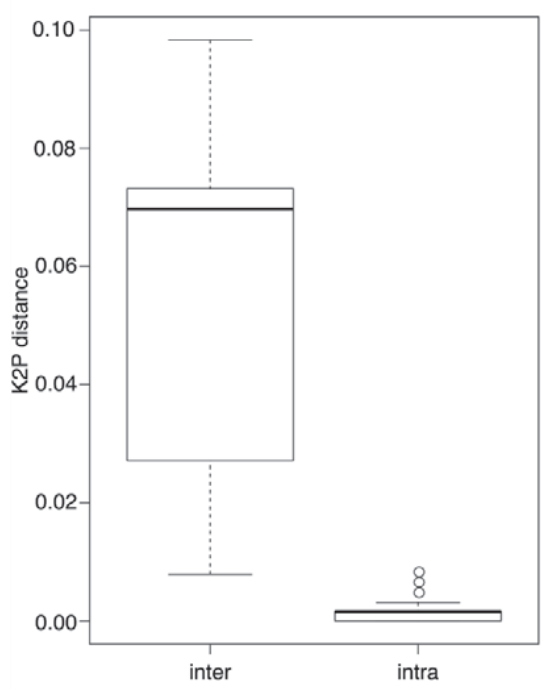

B

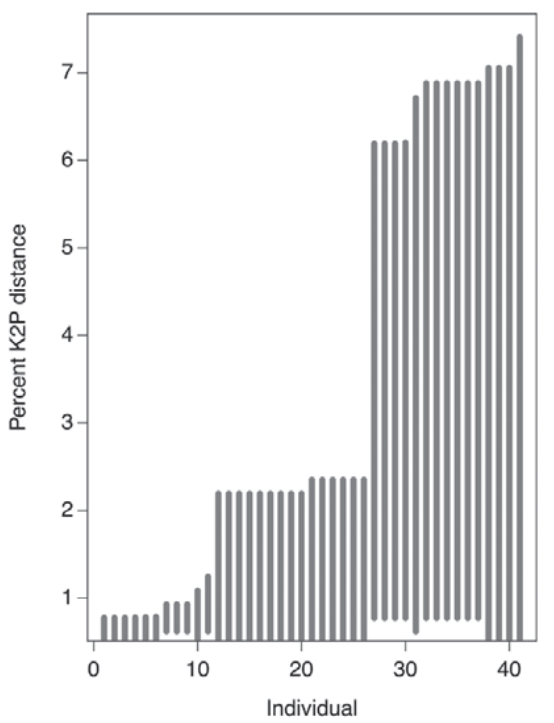

Fig. 10. Evaluation of barcode gaps between sequences of Schilbe intermedius from different countries. A: Boxplot indicating the genetic variation between inter (=interspecific distance calculated here as K2P distance between specimens of different countries) and intra (= intraspecific distance calculated here as K2P distance between specimens within each country); this boxplot clearly shows that specimens between geographic regions are genetically distinct from specimens within countries $(P<0.001$; see text); B: Lineplot of the barcode gap for the silver catfish species; for each individual in the dataset, the grey lines represent the furthest intraspecific distance (bottom of line value), and the closest interspecific distance (top of line value); because all lines are not represented by a dot, this indicates that there is a barcode gap in all sequences 
be recovered and amplified (Goldstein and Desalle 2003, Hajibabaei et al. 2006b, Wandeler et al. 2007). Also, in a situation of high genetic variation between populations (as is the case between African populations of $S$. intermedius), the $650 \mathrm{bp}$-long COI may become problematic as it might require the design of distinct primer sets for each population (Meusnier et al. 2008). Both situations can discount the discriminatory power of the $650 \mathrm{bp}$ of COI, paving a way for the search for a shorter barcode i.e., a mini-barcode (Meusnier et al. 2008). These authors suggested, based on all COI sequences available on GenBank, that a mini-barcode of $100 \mathrm{bp}$ COI provides $90 \%$ identification success, whereas $95 \%$ success were obtained with 250 bp mini-barcodes. In this study however, we did not encounter any difficulty in amplifying the $650 \mathrm{bp}$ COI, indicating that the search for a mini-barcode might not be necessary at least for living organisms and that the universal primer sets amplifying $650 \mathrm{bp}$ COI are still of useful although we found a high genetic variation between populations.

\section{ACKNOWLEDGEMENTS}

This project was partially funded by the Government of Canada through Genome Canada and the Ontario Genomics Institute (2008-OGI-ICI-03). The research was also supported by the ACDB (University of Johannesburg). We thank: Stephanus Voges (Ministry of Fisheries and Marine Resources, Namibia) for his assistance with sample collections; Manny and Carlos Luis for kindly providing assistance for transport of the materials; Michelle Van der Bank for her comments on the early version of this manuscript.

\section{REFERENCES}

Abban E.K., Skibinski D.O.F. 1988. Protein variation in Schilbe mystus (L.) and Eutropius niloticus (Rüppel) (Pisces siluriformes) in the Volta Basin of Ghana, West Africa. Aquaculture Research 19 (1): 25-37.

DOI: $10.1111 /$ j.1365-2109.1988.tb00330.x

Alfaro M.E., Holder M.T. 2006. The posterior and the prior in Bayesian phylogenetics. Annual Review of Ecology, Evolution, and Systematics 37: 19-42.

DOI: 10.1146/annurev.ecolsys.37.091305.110021

Ashley M.V., Wilson M.F., Pergams O.R.W., O'Dowd D.J., Gende S.M., Brown J.S. 2003. Evolutionarily enlightened management. Biological Conservation 111 (2): 115-123. DOI: 10.1016/S0006-3207(02)00279-3

Bell-Cross G. 1972. The fish fauna of the Zambezi River System. Arnoldia (Rhodesia) 5 (29) 1-19.

Bell-Cross G., Minshull J.L. 1988. The fishes of Zimbabwe. Trustees of the National Museums and Monuments of Zimbabwe, Harare.

Bowmaker A.P., Jackson P.N., Jubb R.A. 1978. Freshwater fishes. Pp. 1181-1230 In: Werger M.J.A. (ed.) Biogeography and ecology of southern Africa. W.H. Junk, The Hague.

Brown J.H., Kodric-Brown A. 1977. Turnover rates in insular biogeography: Effect of immigration on extinction. Ecology 58 (2): 445-449. DOI: $10.2307 / 1935620$
Brown S.D.J., Collins R.A., Boyer S., Lefort M.-C., Malumbres-Olarte J., Vink C.J., Cruickshank R.H. 2012. Spider: An R package for the analysis of species identity and evolution, with particular reference to DNA barcoding. Molecular Ecology Resources 12 (3): 562-565. DOI: $10.1111 / \mathrm{j} .1755-0998.2011 .03108 . \mathrm{x}$

Caddy J., Garibaldi L. 2000. Apparent changes in the trophic composition of wild marine harvest: The perspective from FAO capture database. Ocean and Coastal Management 43: $615-655$.

Dankwa H.R., Abban E.K., Teugels G.G. 1999. Freshwater fishes of Ghana: identification, distribution, ecological and economic importance. Koninklijk Museum voor MiddenAfrika Tervuren, België. Annalen Zoloögische Wetenschappen. Vol. 283.

De Vos L. 1984. Preliminary data of a systematic revision of the African species of the family Schilbeidae (Pisces, Siluriformes). Revue de Zoologie Africaine 98: 424-433.

De Vos L., Leveque C. 1983. Etude systématique et morphologique du genre Eutropius en Afrique de L'ouest (Pisces, Schilbeidae). Revue de Zoologie Africaine 97 (3): 469-532.

De Vos L., Skelton P. 1990. Name changes for two common African catfishes. Rehabilitation of Schilbe intermedius Rüppel, 1832 (Siluriformes, Schilbeidae). Cybium 14 (4): 323-326.

Edgar R.C. 2004. MUSCLE: Multiple sequence alignment with high accuracy and high throughput. Nucleic Acids Research 32 (5): 1792-1797. DOI: $10.1093 /$ nar/gkh340

Endler J.A. 1986. Natural selection in the wild. Princeton University Press, Princeton, NJ, USA.

Ernst A., Becker S., Wollenzien U.I.A., Postius C. 2003. Ecosystem-dependent adaptive radiation of picocyanobacteria inferred from 16S rRNA and ITS-1 sequences analysis. Microbiology 149 (1): 217-228.

DOI: $10.1099 / \mathrm{mic} .0 .25475-0$

Faith D.P. 1992. Conservation evaluation and phylogenetic diversity. Biological Conservation 61 (1): 1-10. DOI: 10.1016/0006-3207(92)91201-3

Fitch W.M. 1971. Towards defining the course of evolution: minimum change for a specific tree topology. Systematic Zoology 20 (4): 406-416.

Forest F., Grenyer R., Rouget M., Davies T.J., Cowling R.M., Faith D.P., Balmford A., Manning J.C., Procheş Ş., Van der Bank M., Reeves G., Hedderson T.A.J., Savolainen V. 2007. Preserving the evolutionary potential of floras in biodiversity hotspots. Nature 445 (7129): 757-760. DOI: $10.1038 /$ nature 05587 .

Froese R., Pauly D. (eds.) 2012. FishBase. [version 04/2012] http://www.fishbase.org

Gaigher I.G., Pott R.Mc.C. 1973. Distribution of fishes in southern Africa. South African Journal of Science 69 (1): 25-27.

Geber M.A., Dawson T.E. 1993. Evolutionary responses of plants to global change. Pp. 179-197. In: Kareiva P.M., Kingsolver J.G., Huey R.B. (eds.). Biotic interactions and global change. Sinauer, Sunderland, MA, USA. 
Gilpin M.E., Soulé M.E. 1986. Minimum viable populations: processes of species extinction. Pp. 19-34. In: Soule M.E. (ed.). Conservation biology: the science and scarcity of diversity. Sinauer, Sunderland, MA, USA.

Goldstein P.Z., Desalle R. 2003. Calibrating phylogenetic species formation in a threatened insect using DNA from historical specimens. Molecular Ecology 12 (7): 1993-1998. DOI: 10.1046/j.1365-294X.2003.01860.x

Greenwood P.H. 1983. The zoogeography of African freshwater fishes: bioaccountancy or biogeography? Pp. 179-199. In: Sims R.W., Price J.H., Whalley P.E.S. (eds.) Evolution, time and space: The emergence of the biosphere. Academic Press, London, UK.

Hajibabaei M., Janzen D.H., Burns J.M., Hallwachs W., Hebert P.D.N. 2006a. DNA barcodes distinguish species of tropical Lepidoptera. Proceedings of the National Academy of Sciences of the United States of America 103 (4): 968-971.

DOI: $10.1073 /$ pnas.0510466103

Hajibabaei M., Smith M.A., Janzen D.H., Rodriguez J.J., Whitfield J.B., Hebert P.D.N. 2006b. A minimalist barcode can identify a specimen whose DNA is degraded. Molecular Ecology Notes 6 (4): 959-964. DOI: 10.1111/j.1471-8286.2006.01470.x

Hajibabaei M., Singer G.A.C., Clare E.L., Hebert P.D.N. 2007. Design and applicability of DNA arrays and DNA barcodes in biodiversity monitoring. BMC Biology 5: 24. DOI: $10.1186 / 1741-7007-5-24$

Hardman M. 2005. The phylogenetic relationships among nondiplomystid catfishes as inferred from mitochondrial cytochrome b sequences; the search for the ictalurid sister taxon (Otophysi: Siluriformes). Molecular Phylogenetics and Evolution 37 (3): 700-720.

DOI: 10.1016/j.ympev.2005.04.029,

Hebert P.D.N., Stoeckle M.Y., Zemlak T.S., Francis C.M. 2004. Identification of birds through DNA barcodes. PLoS Biology 2 (10): E312.

DOI: 10.1371/journal.pbio.0020312

Hillis D.M., Bull J.J. 1993. An empirical test of bootstrapping as a method for assessing confidence in phylogenetic analysis. Systematic Biology 42 (2): 182-92.

DOI: $10.1093 /$ sysbio/42.2.182

Hughes J.B., Daily G.C., Ehrlich P.R. 1997. Population diversity: Its extent and extinction. Science 278 (5338): 689-692. DOI: $10.1126 /$ science.278.5338.689

Kembel S.W., Cowan P.D., Helmus M.R., Cornwell W.K., Morlon H., Ackerly D.D., Blomberg S.P., Webb C.O. 2010. Picante: R tools for integrating phylogenies and ecology. Bioinformatics 26 (11): 1463-1464.

DOI: 10.1093/bioinformatics/btq166

Kettlewell M.G. 1972. The evolution of melanism. Oxford University Press, Oxford, UK.

Kinnison M.T., Hendry A.P. 2001. The pace of modern life II: from rates of contemporary microevolution to pattern and process. Genetica 112-113 (1): 145-164.

DOI: $10.1023 / A: 1013375419520$

Loarie S.R., Duffy P.B., Hamilton H., Asner G.P., Field C.B., Ackerly D.D. 2009. The velocity of climate change. Nature
462 (7276): 1052-1055.

DOI: 10.1038 /nature08649

Mace G., Masundire H., Baillie J.E.M. 2005. Biodiversity. Pp. 77-122. In: Hassan R., Scholes R., Ash N. (eds.) Ecosystems and human well-being: Current state and trends: findings of the condition and trends working group. Island Press, Washington, DC, USA.

Meusnier I., Singer G.A.C., Landry J.-F., Hickey D.A., Hebert P.D.N., Hajibabaei M. 2008. A universal DNA mini-barcode for biodiversity analysis. BMC Genomics 9: $1-4$. DOI: $10.1186 / 1471-2164-9-214$

Nelson J.S. 1994. Fishes of the world, 3rd edn. Wiley, New York, NY, USA.

Nwani C.D., Becker S., Braid H.E., Ude E.F., Okogwu O.I., Hanner R. 2011. DNA barcoding discriminates freshwater fishes from southeastern Nigeria and provides river systemlevel phylogeographic resolution within some species. Mitochondrial DNA 22 (S1): 43-51.

DOI: $10.3109 / 19401736.2010 .536537$

Olwoch J.M., Van Jaarsveld A.S., Scholtz C.H., Horak I.G. 2007. Climate change and the genus Rhipicephalus (Acari: Ixodidae) in Africa. Onderstepoort Journal of Veterinary Research 74 (1): 45-72.

DOI: $10.4102 /$ ojvr.v74i1.139

Paradis E., Claude J., Strimmer K. 2004. Ape: analyses of phylogenetics and evolution in R language. Bioinformatics 20 (2): 289-290.

DOI: $10.1093 /$ bioinformatics/btg412

Partridge T.C., Maud R.R. 1987. Geomorphic evolution of southern Africa since the Mesozoic. South African Journal of Geology 90 (2): 165-184.

Pimm S.L., Russell G.J., Gittleman J.L., Brooks T.M. 1995. The future of biodiversity. Science 269 (5222): 347-350. DOI: $10.1126 /$ science.269.5222.347

Posada D. 2008. jModelTest: phylogenetic model averaging. Molecular Biology and Evolution 25 (7): 1253-1256. DOI: $10.1093 / \mathrm{molbev} / \mathrm{msn} 083$

Posada D., Buckley T.R. 2004. Model selection and model averaging in phylogenetics: advantages of Akaike information criterion and Bayesian approaches over likelihood ratio tests. Systematic Biology 53 (5): 793-808.

DOI: $10.1080 / 10635150490522304$

Radulovici A.E., Archambault P., Dufresne F. 2010. DNA Barcodes for marine biodiversity: Moving fast forward? Diversity 2 (4): 450-472.

DOI: $10.3390 / \mathrm{d} 2040450$

Rice K.J., Emery N.C. 2003. Managing microevolution: Restoration in the face of global change. Frontiers in Ecology and the Environment 1 (9): 469-478.

Roberts T.R. 1975. Geographical distribution of African freshwater fishes. Zoological Journal of the Linnean Society 57 (4): 249-319.

DOI: 10.1111/j.1096-3642.1975.tb01893.x

Ronquist F., Huelsenbeck J.P. 2003. MrBayes 3: Bayesian phylogenetic inference under mixed models. Bioinformatics 19 (12): 1572-1574.

DOI: $10.1093 /$ bioinformatics/btg180 
Sandel B., Arge L. Dalsgaard B., Davies R.G., Gaston K.J., Sutherland W.J., Svenning J.-C. 2011. The Influence of late quaternary climate-change velocity on species endemism. Science 334 (6056): 660-664. DOI: $10.1126 /$ science. 1210173

Sanderson M.J. 2002. Estimating absolute rates of molecular evolution and divergence times: A penalized likelihood approach. Molecular Biology and Evolution 19 (1): 101-109.

Stockwell C.A., Hendry A.P., Kinnison M.T. 2003. Contemporary evolution meets conservation biology. Trends in Ecology and Evolution 18 (2): 94-101. DOI: $10.1016 / \mathrm{S} 0169-5347(02) 00044-7$

Swofford D.L. 2003. PAUP*4.0: Phylogenetic Analysis Using Parsimony (andOther Methods). Sinauer Associates Inc., Sunderland, MA, USA.

Tajima F. 1983. Evolutionary relationship of DNA sequences in finite populations. Genetics 105 (2): 437-460.

Trauth M.H., Maslin M.A., Deino A., Strecker M.R. 2005. Late cenozoic moisture history of East Africa. Science 309 (5743): 2051-2053.

DOI: $10.1126 /$ science. 1112964

Van der Bank F.H., Engelbrecht G.D., Sauer-Gürth H., Wink M., Mulder P.F.S. 1998. Allozyme and DNA sequence data support speciation between northern and southern populations of the silver catfish Schilbe intermedius (Rüppel, 1832). Comparative biochemistry and physiology. Part A: Molecular and Integrative Physiology 120 (3): 531-543.

DOI: 10.1016/S1095-6433(98)10063-6

Wandeler P., Hoeck P.E.A., Keller L.F. 2007. Back to the future: museum specimens in population genetics. Trends in Ecology Evolution 22 (12): 634-642.

DOI: $10.1016 /$ j.tree.2007.08.017

Ward R.D., Zemlak T.S., Innes B.H., Last P.R., Hebert P.D.N. 2005. DNA barcoding Australia's fish species.
Philosophical Transactions of the Royal Society Part B: Biological Sciences 360 (1462): 1847-1857.

DOI: $10.1098 /$ rstb.2005.1716

Wellington J.H. 1955. Southern Africa-A geographic study. Vol. 1. Physical geography. Cambridge University Press, Cambridge, UK.

Western D. 2001. Human-modified ecosystems and future evolution. Proceedings of the National Academy of Sciences of the United States of America 98 (10): 5458-5465.

DOI: 10.1073/pnas. 101093598

Wilcox T.P., Zwickl D.J., Heath T.A., Hillis D.M. 2002. Phylogenetic relationships of the dwarf boas and a comparison of Bayesian and bootstrap measures of phylogenetic support. Molecular Phylogenetics and Evolution 25 (2): 361-371.

DOI: 10.1016/S1055-7903(02)00244-0

Willis C.G., Ruhfel B., Primack R.B., Miller-Rushing A.J., Davis C.C. 2008. Phylogenetic patterns of species loss in Thoreau's woods are driven by climate change. Proceedings of the National Academy of Sciences USA 105 (44): 17029-17033.

DOI: $10.1073 /$ pnas.0806446105

Willis C.G., Ruhfel B.R., Primack R.B., Miller-Rushing A.J., Losos J.B., Davis C.C. 2010. Favourable climate change response explains non-native species' success in Thoreau's Woods. PLoS ONE 5 (1): e8878.

DOI: 10.1371/journal.pone.0008878

Yessoufou K., Daru B.H., Davies T.J. 2012 Phylogenetic patterns of extinction risk in the Eastern Arc Ecosystems, an African biodiversity hotspot. PLoS ONE 7 (10): e47082. DOI: 10.1371/journal.pone.0047082

Received: 22 June 2012

Accepted: 27 October 2012 Published electronically: 31 December 2012 